Extended Abstract

\title{
Information quality and truth: consumerism, deception and the postmodern age
}

\author{
${ }^{1}$ Arthur R. Taylor, Ph.D. Rider University, 2083 Lawrenceville Rd., Lawrenceville, NJ 08648 * \\ E-Mails: ataylor@rider.edu
}

* Author to whom correspondence should be addressed; Tel.: (609) 895-5514

\section{Introduction}

Churchman recognized the importance of information (knowledge) in the systems approach and cited the potential for deception throughout (Churchman, 1968). If information quality includes criteria for veracity, then information which deceives can be considered information of poor quality. Information quality perceived as an objective truth (through Churchman's guarantor perhaps) provides a useful component in the utilitarian model of information quality. But when viewed from a subjective perspective, the concept of information veracity raises complex philosophical questions concerning the ethics and values of the subject.

Representations of information quality imply a clear and understandable presentation of the information (Arazy \& Kopak, 2011; Lee, Strong, Kahn and Wang, 2002; Liu, 2004). Information quality criteria include accuracy and objectivity of the author and source. Information which is accurate is considered reliable and correct, and information that is complete provides all necessary information from a utilitarian perspective. Information which is objective provides an impartial view of the topic. However, information which is false is still considered information, but evaluated under various objective criteria may not be considered quality information. Information quality is one dimension of relevance as part of information consumption (Taylor, 2012a).

\section{Methods}

The cross-disciplinary approach used here will examine the consumption of information within the context of the systems approach, information science relevance theory, consumerism, postmodernism, and significant changes in information technology which provide nearly ubiquitous access to all forms of information. Relevant arguments and theory will be presented as evidence of the impact of this convergence on perceptions of information quality in relation to subjective values, and the pursuit of an objective truth as part of a utilitarian model of information consumption. 
If valuation of information quality includes truth, then a discussion of subjective perceptions of truth are warranted. Specifically interpretations of truth in relation to spiritual and ethical value systems will be examined as part of this process.

\section{Discussion}

Relevance theory in information science examines information use from a user's perspective as a utilitarian concept. A document retrieved from an IR system is considered relevant if it has utility in fulfilling the information requirement of the user. Evaluations of relevance by the user involve the use of various relevance criteria for document evaluation which include characteristics of information quality. This is by definition a subjective view of the document's relevance. Interpretations of the characteristics of the document are also subjective in this approach, and information quality characteristics including veracity, authenticity, qualifications of the author and bias are also subjective. These documents and their constituent information are therefor evaluated in the context of the subject's worldview. The notion of truth value becomes part of this evaluation. In the utilitarian view of information consumption, a false document may in fact have value and be considered relevant Additionally, a document evaluated as true based on a subject's worldview, may have an objective evaluation of false (perhaps biased) but still be considered relevant and useful to the subject.

Information production and consumption as part of a market add additional complexities and create a further perversion of the information gathering process as part of a systems approach. When information consumption is viewed from the perspective of consumerism in a market it is cast into a capitalistic economic model where information consumers may view information as yet another market product to be consumed at the lowest cost. Information producers seek profit by lowering the cost of production and enticing consumption through production of information which suits the bias of a particular audience. Due to the confluence of these forces, information quality, including veracity, may be of limited concern where information is simply a product in a market transaction. Evidence from a variety of sources would suggest that information distributed in an economic system which values capital and subsumes or possibly ignores ethics and morality, the valuation of truth in information becomes even more suspect.

Further analysis can consider dimensions of information quality in relation to consumerism and postmodernism. Postmodern thought embraces the market and consumerism. Information production (journalism, mass media) is yet another cultural product in the market. Information production cast into the market framework is influenced by the revised sequence of capital consumer markets where demand control through advertising and marketing and pursuit of additional surplus value impact the quality of information. This leads to biased and fragmented dissemination of information. Breakdown of traditional control structures is another side effect of this convergence, leading to prosumerism (amateur) information dissemination with similar impacts on information quality.

Information is consumed from a source. Media products provide information and in a world with ubiquitous technology the Internet increasingly provides access to these media sources and thus represent a significant nexus of control. Managers at Google, the most popular Internet search engine in the world, claim to answer more than one billion search queries a day (Google-1, 2013; Sullivan, 2013). For a significant demographic segment of the general population, almost any consumption of 
information is filtered through an Internet search engine operated by a private business (Rowlands et al, 2008; Pew, 2012). That these search engines are owned and operated by private, for-profit businesses is yet another problematic dimension of the consumption of information.

\section{Results}

In a world where information is produced and distributed across vast information networks, information production time has been drastically shortened and the information produced has become increasingly fragmented. As an extension of the postmodern age, current technology creates a world where information from dubious sources surrounds us and pervades our senses. Interpreting this fragmented and disjointed information in relation to an internal system of values is increasingly challenged leading to further questions of truth value.

Capitalism is an amoral economic system for the distribution of scarce resources, and thus the unregulated system itself has no recognition of truth value for the information which has become a product in a market transaction. In businesses which are managed and operate with little regard for social consequences, the ethics or value of truth or information quality may be greatly reduced. In a business with profit motive, veracity or quality of information may be secondary to profit, or without social pressure to the contrary, information quality may not even be a consideration. Postmodernism acknowledges the consolidation of knowledge, technology and production and recognizes the power that information holds in this scenario.

The postmodernists readily acknowledge the subjective truth and find difficulty in the pursuit of objective truths. Consumerism converges with postmodernism in the production of knowledge in a capitalistic society. Jean-Francois Lyotard saw the growing connection between knowledge production and capital markets and saw the potential for problems. As he foresaw, knowledge is now a salable commodity in an environment where it has lost its truth value and is consumed largely on the basis of its utility value (use-value) (Lyotard, 1984). It is possible that those who have come of age with the pervasive information cacophony of the Internet gather information from fragmented, disjointed information sources of dubious value and have little concern about the veracity or authority of those sources. They evaluate information sources as subjective, not objective, and regard critical evaluation of the information and the source as a task to be managed by some other individual or by the technology involved (Gross and Latham, 2011; Taylor, 2012b, Harley et al, 2001).

\section{Conclusions}

This discussion provides some evidence that the convergence of consumerism, postmodernism and broad technical access to a variety of information sources has had an impact on both the perception of what information is and on the quality of information being disseminated and consumed. The question of moral, ethical and spiritual values within this convergence were examined. It provides a basis for further discussion and examination. 


\section{References and Notes}

Arazy, O., \& Kopak, R. (2011). “On the measurability of information quality”, Journal of the American Society for Information Science and Technology, 62(1), 89-99.

Churchman, C. W. (1968) The Systems Approach. New York: Dell Publishing.

Google (2013), Facts about Google. retrieved on 6/27/2013 available at http://www.google.com/competition/howgooglesearchworks.html

Gross, M., \& Latham, D. (2011). Experiences with and perceptions of information: A phenomenographic study of first-year college students. Library Quarterly, 81(2),161-186.

Gross, M., \& Latham, D. (2011). Experiences with and perceptions of information: A phenomenographic study of first-year college students. Library Quarterly, 81(2),161-186.

Harley, B.,, Dreger, M., \& Knobloch, P. (2001), The postmodern condition: students, the Web, and academic library services. Reference Services Review, 29(1),23-32.

Harley, B.,, Dreger, M., \& Knobloch, P. (2001), The postmodern condition: students, the Web, and academic library services. Reference Services Review, 29(1),23-32.

Lee, Y.W., Srong, D.M., Kahn, B.K., Wang, R.Y. (2002). AIMQ: A methodology for information quality assessment. Information and Management, 40(2), 133-146.

Liu, Z. (2004). Perceptions of credibility and scholarly information on the web.. Information Processing and Management, 40(6), 1027-1038.

Lyotard, J.F (1984), The Postmodern Condition: A Report on Knowledge, Manchester: Manchester University Press.

Pew (2012), “Pew Research Center - Search Engine Use 2012”. retrieved on 6/30/2013 available at http://www.pewinternet.org/Press-Releases/2012/Search-Engine-Use-2012.aspx\#

Rowlands, I., Nicholas, D., Williams, P., Huntington, P., Fieldhouse, M., Gunter, B., Withey, B., Jamali, H. R., Dobrowolski, T., and Tenopir, C. (2008), The Google generation: the information behaviour of the researcher of the future. ASLib Proceedings, 60(4),290 - 310.

Sullivan, D. (2013). Google Still World's Most Popular Search Engine By Far, But Share Of Unique Searchers Dips Slightly. retrieved on 6/27/2013 available at http://searchengineland.com/google-worlds-most-popular-search-engine-148089

Taylor, A. R. (2012a), User relevance criteria choices and the information search process. Information Processing and Management, 48(12),136-153.

Taylor, A. (2012b. "A study of the information search behaviour of the millennial generation" Information Research, 17(1) paper 508. [Available at http://InformationR.net/ir/171/paper508.html] 